\title{
Increasing Vegetable Oil Demand in China: Impacts on the International Soybean Market
}

\author{
Hongmei Jia \\ Texas A\&M University Commerce \\ Yanxi Li \\ University of Kentucky
}

Xiang Li

Increases in income and urbanization lead to strong demand for edible oil in China, which impacts global soybean trade. This study reviews the history of China's soybean industry and vegetable oil consumption patterns, compares the demand for vegetable oil with demand in Japan and South Korea, and then forecasts China's demand for vegetable oil and soybean imports in the coming decades.

Keywords: income increases, soybean import, urbanization, vegetable oil consumption

\section{INTRODUCTION}

China has over one-fifth of the world's consumers with an economy growing at 7\%-8\% annually in the last three decades. The rationing of edible oil in urban China was officially eliminated in 1993. Domestic markets for edible oils and fats have been driven by growing per capita income since then. By 1999, China had become the world's largest importing country of soybean, rapeseed, and palm oils, despite restrictive import quotas. According to the Food and Agriculture Organization of the United Nations (FAO), vegetable oil consumption per capita each year in China increased from $2.4 \mathrm{~kg}$ in 1978 to $8.9 \mathrm{~kg}$ in 2010, which is a $270 \%$ increase. Among these oil crops, soybean consumption increased most significantly, especially in the past decade. In 2003, China imported 23.2 million tons of soybeans and surpassed the European Union (EU) to become the largest soybean importer in the world. In 2010, the import volume was 57 million tons, accounting for $61 \%$ of the world soybean trade. This paper reviews China's soybean production, imports, exports and consumption in the last three decades, analyzes the driving force behind the increasing demand, studies the structural change in vegetable oil consumption, and forecasts the trends for vegetable oil consumption and the soybean trade in China.

\section{BACKGROUND}

The soybean is a species of legume, which is classed as an oilseed by FAO. The first domestication of the soybean has been traced to the eastern half of North China in the eleventh century B.C. The soybean 
was one of the five main plant foods of ancient China along with rice, wheat, barley and millet. Before the 1960s, China accounted for about one quarter of world soybean production. With increasing soybean cultivation in the United States and South American countries in subsequent decades, China's share of worldwide production has continually decreased, although its annual production has always increased. In 2011, soybean production in China was 14.5 million tons and accounted for $5.6 \%$ of total world production.

Soybeans were first introduced into the American Colonies in 1765. Most of the early introductions were obtained from China, Japan, India, Manchuria, Korea, and Taiwan. The U.S. dominated world soybean production through the 1950 's, 60 's, and 70 's, growing more than $75 \%$ of the world soybean crops. A worldwide shortage of feed protein in the early 1970's led to the initiation of large-scale soybean production in several South American countries, most notably Argentina and Brazil. By 2011, the U.S.'s share of the world's soybean production had shrunk to 32\% while Argentina's and Brazil's had increased to $19 \%$ and $29 \%$, respectively.

Traditional food uses of soybeans in China include direct eating, soy milk, tofu, tofu skin, and soy sauce. However, soybeans were not used to any great extent for fodder for livestock or vegetable oil in China. Globally, the majority of the soybean crop is processed into oil and meal. A 60-pound bushel of soybeans yields about 11 pounds of oil or about 48 pounds of meal. Oil extracted from soybeans is made into shortening, margarine, cooking oil, and salad dressings. In 2011, soybean oil accounted for $25 \%$ of total vegetable oils consumed in the world, ranking second after palm oil, which was $30 \%$. Soybean oil is also used in industrial paint, varnishes, caulking compounds, linoleum, printing inks, and other products. Development efforts in recent years have resulted in several soybean oil-based lubricant and fuel products that can replace non-renewable petroleum products. Soybean meal (also known as soybean oil cake) is a solid residue bi-product, created after grinding the soybean to extract soybean oil. It is widely used as a filler and source of protein in animal diets, including pig, chicken, cattle, horse, sheep, and fish feed.

\section{CHINA'S SOYBEAN TRADE}

China has been a net exporter of soybeans since 1970. However, it mainly consumes its own production with little imports and exports before 1995, because the Chinese government sets a quota for soybean imports. It imposes a 3\% tariff on imports under quota and a $114 \%$ tariff for import over quota. The monopoly structure of China's state trading may hinder the China's agricultural trade (Drewnowski and Popkin, 1997). After 1996, the tariff rate was set to $3 \%$ and the quota was eliminated, which boosted the import of soybeans (figure 1). China's WTO accession agreement in 2003 weakens the state monopolies further. Imports of soybeans first exceeded domestic production in 2003, and imports have increased continually in the following years. In 2010 , soybean imports accounted for $75 \%$ of the total domestic supply. 
FIGURE 1

CHINA'S SOYBEAN IMPORTS/EXPORTS

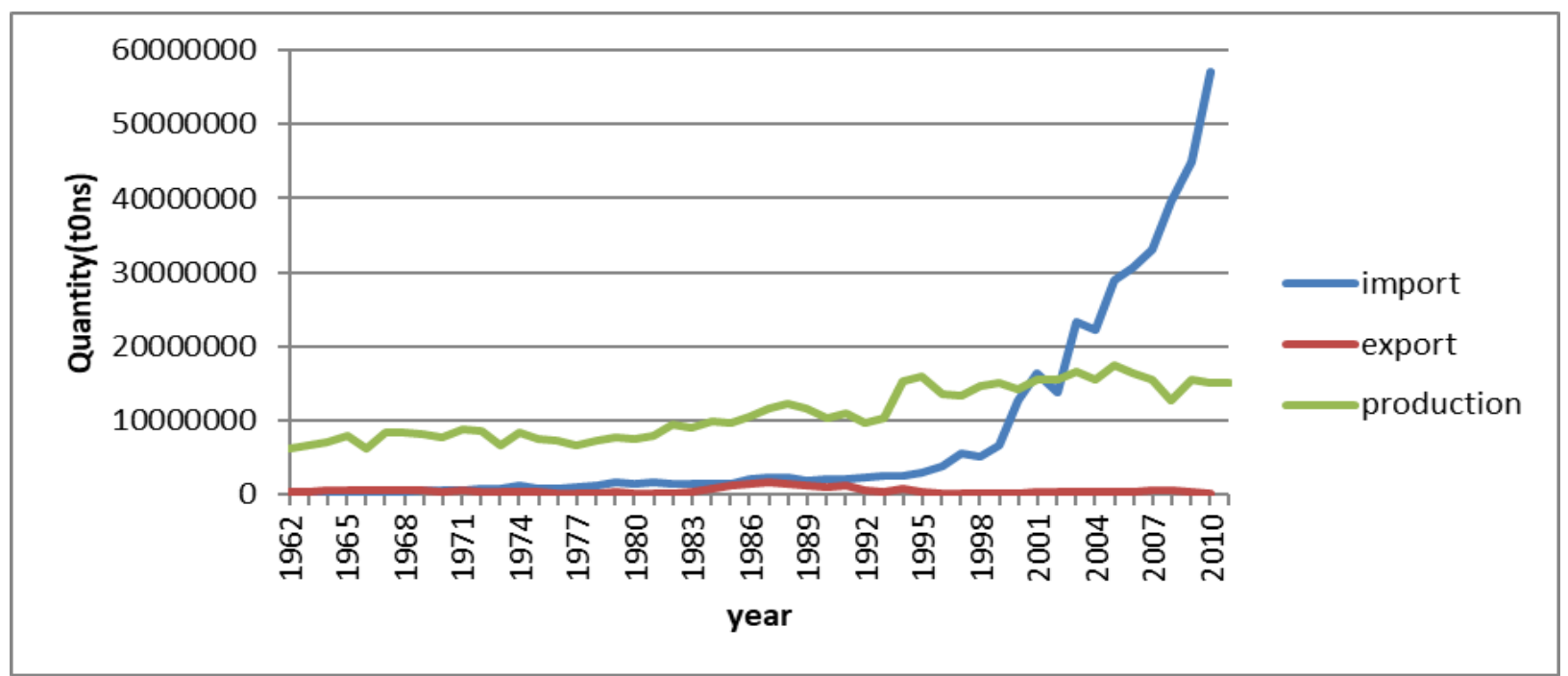

Data Source: FAO

The top three exporters to China are the United States, Brazil, and Argentina. In 2010, they supplied 96\% of China's total soybean imports. The market share for each exporter is shown in figure 2.

FIGURE 2

SHARE OF CHINA'S SOYBEAN IMPORTS IN 2010

\section{Share in China's Soybean Imports}

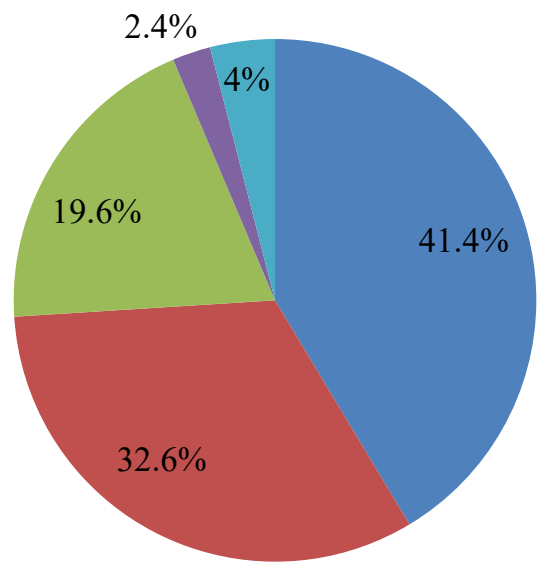

- United States of America

n Brazil

- Argentina

- Uruguay

athers

Data Source: FAO 
FIGURE 3

SOYBEAN: CHINA'S IMPORT SHARES AND PRICES

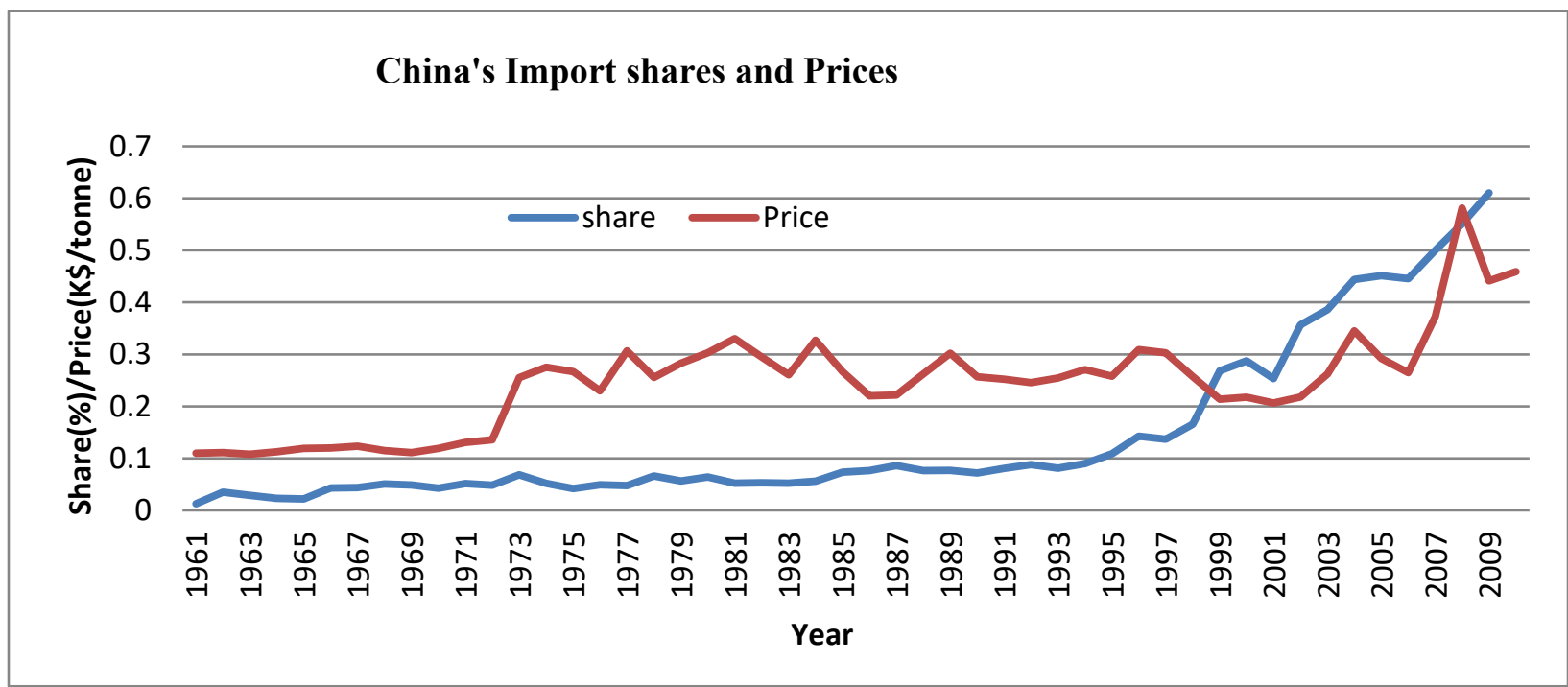

Data Source: FAO

With the biggest share of the international soybean market, China's imports impact global soybean prices greatly. Although there are other reasons for soaring soybean prices in recent years, such as the demand for biofuel, the increasing demand from China pushed the soybean price higher in the past two decades. Figure 3 shows the long run trend of this link. From 2000, in which year China had a $28 \%$ share of the soybean trade, China's import prices are highly correlated with its market share. A correlation analysis shows the correlation coefficient is 0.81 . An unexpected low price appeared in 2009 due to the prospects of record crops in South America (USDA, 2010)

\section{DRIVING FORCE OF THE INCREASING DEMAND}

\section{Income Increases and Urbanization}

Many Chinese scholars attribute the increase of soybean imports to the impact of GMO soybean cultivation in the United States and the South American countries. They believe cheap soybeans from these countries damage domestic farmers' incentive for soybean cultivation, leading to the shortage of domestic supply of soybeans in recent years. This explanation is weak. Figure 4 shows that there is no remarkable shrinkage of the soybean harvest area in past two decades. Soybean production remained above 14 million tons in most years. In light of the fact that China's population only increased 16\% in the 1990's and 2000's, from 1.16 billion in 1991 to 1.35 billion in 2011, the huge shortage of soybean supply in recent years is clearly due to reasons other than increasing population and decreasing cultivation. 
FIGURE 4

SOYBEAN CULTIVATION AND PRODUCTION IN CHINA

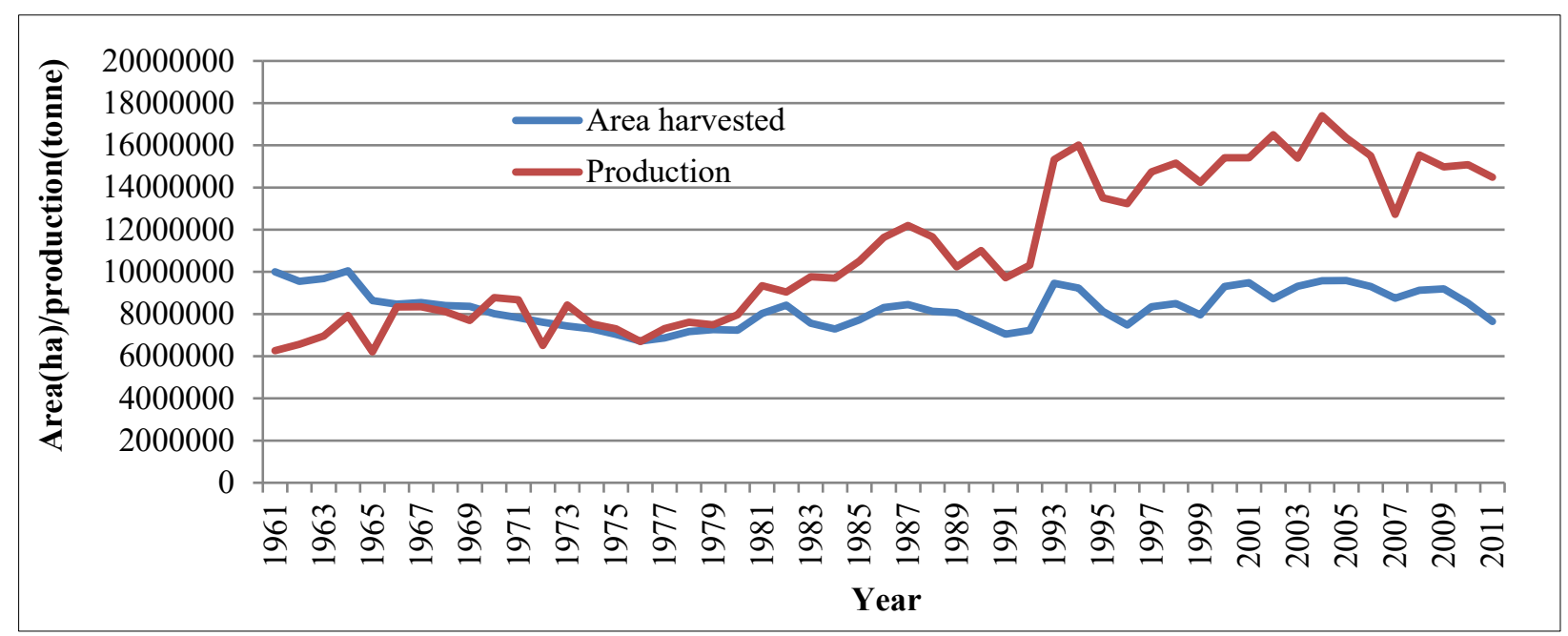

Data Source: FAO

China has a much larger labor force employed in agriculture than other developed countries and most of its population lives in rural areas. Traditionally, grains (mostly rice and wheat) and vegetables make up the main sources of food consumption in China. Consumption of fruits, sugar and sweeteners, and fats and oils is lower. These differences in food consumption between China and the rest of the world reflect a combination of low per capita incomes in China and differing tastes and preferences. China's high consumption and production of vegetables, which yield high quantities per unit of land, makes efficient use of scarce land resources. As incomes rise and populations become more urbanized, consumption of all foods will grow, but consumption of meat, fruits, fish, fats and oils, and sugar and sweeteners will grow the fastest. Societies enter different stages of what has been called the nutrition transition. Diets high in complex carbohydrates and fiber give way to more varied diets with a higher proportion of fats, saturated fats, and sugars. Drewnowski and Popkin (1997) confirmed that positive income elasticity between income and fat consumption exists in China for a wide range of incomes. They also expect that the early stages of the nutrition transition in China would be accounted for by sharply increased availability of vegetable oil. Across Asia, the behavior of consumers changes dramatically as countries urbanize. Urban dwellers consume less rice and more meats, milk products, and fish than do their rural counterparts, even after accounting for the differences in income and prices. China is undergoing mass urbanization during the beginning of the 21 st century, which has dramatic effects on food consumption. According to the China Bureau of Statistics, only $36 \%$ of the population lived in cities and towns in 2000 . This urbanization rate was $10 \%$ points below the world average and lower than the rate in many other countries at similar development levels. In 2011, the urbanization rate had reached 51\%. This population shift has a great impact on national food consumption because consumption patterns are inherently different for rural and urban consumers. Income differentials, expenditure growth, rates of change of population, and other demographic factors also vary dramatically between rural and urban regions (Huang, et al., 1999). Increased income and urbanization in China helped propel the growth in demand for animal protein products and vegetable oils. Soybean demand derives from increased consumption of soybean oil and soybean meal, which is mainly fed to livestock and its demand derives from demand for meat and other animal products. 

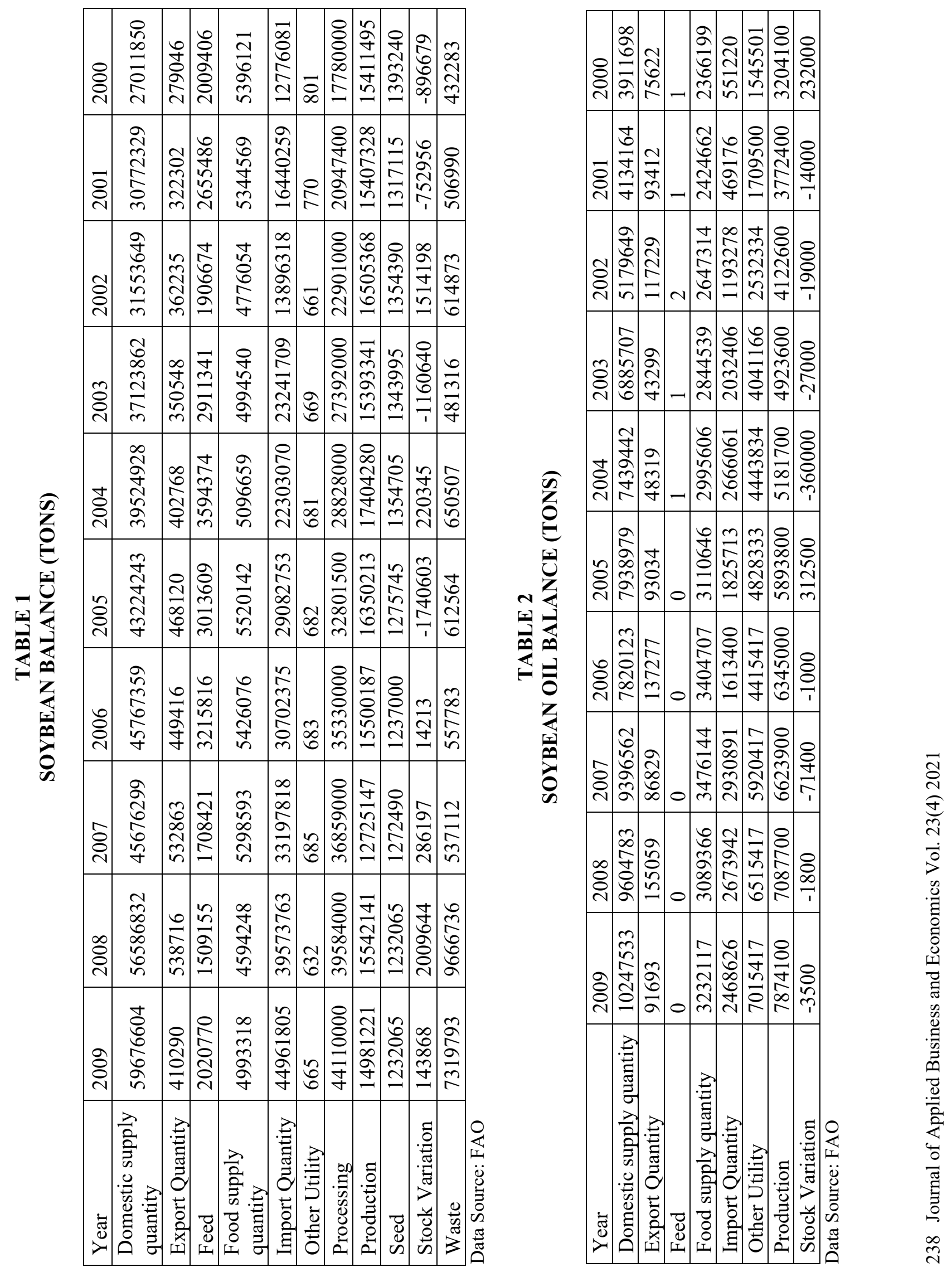
Table 1 shows that, from 2000 to 2009, the soybean supply remained at about 5 million tons while soybean oil supply increased from 2.4 million tons to 3.2 million tons (figure 2). At the same time, the total soybean oil supply almost tripled, increasing from 3.9 million tons to 10.2 million tons. Within the domestic supply, the supply of soybean oil for other uses increased from 1.5 million tons to 7.0 million tons. Based on information from the oil crush industry, most of the soybean oil in the other-use category goes to the food manufacturing industry and restaurants, and to a lesser extent for industrial usage, which means that most of the other-utility soybean oil is finally consumed as food but not counted in the food supply. Comparing the quantities of processed and imported soybeans in table 1 , as well as the soybean oil production in table 2 , we reasonably conclude that over $95 \%$ of the imported soybeans are crushed into soybean oil and soybean meal, which supply the increasing food and feed demands in recent years.

The increasing demand partly comes from income growth and partly from urbanization. Table 3 shows the urban population proportion and per capita consumption of vegetable oil by urban and rural households.

\section{TABLE 3 \\ PER CAPITA CONSUMPTION OF VEGETABLE OIL (KG) BY URBAN AND RURAL HOUSEHOLDS}

\begin{tabular}{|l|l|l|l|l|l|l|l|l|}
\hline & & & \multicolumn{6}{|l|}{ Urban } \\
\cline { 4 - 9 } & $\begin{array}{l}\text { Urban } \\
\text { population } \\
\text { Proportion } \\
\text { (\%) }\end{array}$ & Rural & National & $\begin{array}{l}\text { Lowest } \\
\text { income } \\
\text { households } \\
\text { (first decile } \\
\text { group) }\end{array}$ & $\begin{array}{l}\text { Middle } \\
\text { income } \\
\text { household } \\
\text { (third } \\
\text { quintile } \\
\text { group) }\end{array}$ & $\begin{array}{l}\text { Upper } \\
\text { middle } \\
\text { income } \\
\text { household } \\
\text { (fourth } \\
\text { quintile } \\
\text { group) }\end{array}$ & $\begin{array}{l}\text { High } \\
\text { income } \\
\text { household } \\
\text { (ninth } \\
\text { decile } \\
\text { group) }\end{array}$ & $\begin{array}{l}\text { Highest } \\
\text { income } \\
\text { household } \\
\text { (tenth } \\
\text { decile } \\
\text { group) }\end{array}$ \\
\hline 2011 & 51.27 & 6.6 & 9.26 & 8.4 & 9.7 & 9.5 & 9.31 & 8.89 \\
\hline 2010 & 49.95 & 6.31 & 8.84 & 7.82 & 9.14 & 9.15 & 9.08 & 8.74 \\
\hline 2009 & 48.34 & 5.42 & 9.67 & 8.26 & 10.09 & 10.22 & 9.73 & 9.92 \\
\hline 2008 & 46.99 & 5.36 & 10.27 & 8.69 & 10.72 & 10.73 & 10.81 & 10.37 \\
\hline 2007 & 45.89 & 5.06 & 9.63 & 8.13 & 10.05 & 10.22 & 9.93 & 9.61 \\
\hline 2006 & 44.34 & 4.72 & 9.38 & 8.7 & 9.82 & 9.38 & 9.25 & 8.46 \\
\hline 2005 & 42.99 & 4.9 & 9.25 & 8.69 & 9.62 & 9.58 & 8.97 & 8.39 \\
\hline 2004 & 41.76 & 4.31 & 9.29 & 8.87 & 9.4 & 9.47 & 9.2 & 8.39 \\
\hline 2000 & 36.22 & 5.45 & 8.16 & 7.8 & 8.19 & 8.13 & 7.89 & 8.16 \\
\hline 1995 & 29.04 & 4.25 & 7.11 & 6.43 & 7.09 & 7.34 & 7.61 & 7.66 \\
\hline 1990 & 26.41 & 3.54 & 6.4 & 5.04 & 6.16 & 6.47 & 7.17 & 7.62 \\
\hline
\end{tabular}

Data source: National Bureau of Statistics of China

Per capita consumption of vegetable oils in Urban China increased from 6.4 kilograms in 1990 to 9.3 kilograms in 2004 and then remained at that level until 2011. Rural consumption of vegetable oil grew continually from 3.5 kilograms in 1990 to 6.6 kilograms per person in 2011. The urban population proportion almost doubled in those two decades. The income growth and urbanization together led to the vegetable oil demand increase before 2004. After that, the main driving force was the consumption pattern change caused by urbanization.

\section{Change in Vegetable Oil Consumption Pattern}

Historically, rapeseed oil was the leading vegetable oil consumed in China, but soybean oil supply grew rapidly and surpassed rape and mustard oil supply in 2001. Rapeseed production competes in land use with winter wheat production, and its acreage could not be vastly expanded. Figure 3 shows the shares of 
vegetable oil supply from 2000 to 2009. The top four items are soybean oil, palm oil, rape and mustard oil, and ground nuts oil. Soybean oil consumption grew faster than consumption of most other vegetable oils, including peanut oil, cottonseed oil, and sesame oil. From the late 1990s, the soybean crushing industry developed quickly in China, especially after 2000. Crushing plants in Heilongjiang, Shandong, Jiangsu, Guangdong, and Sichuan provinces expanded. According to the Ministry of Commerce of China, the crushing capacity was less than 70 thousand tons per day in 2000. By the end of 2010, the crushing capacity had increased to 270 thousand tons per day, over 78 million tons per year. Since the quantities of oil exports are less than 0.1 million tons in most years, the rapidly increasing crushing capacity is induced by domestic demand for soybean oil and soybean meal. Figure 5 shows the supply share of each vegetable oil. The supply of ground nuts oil, a traditional oil in China, remained relatively constant in the decades of the 1990s and 2000s. Most of the increasing supply came from soybean oil, palm oil, and rape and mustard oil. In 2009, soybean oil accounted for 35\% of total vegetable oil supply, ranking first among all vegetable oils. Palm oil supply increased quickly in the 2000 s. It will be a strong competitor with soybean oil in the future.

FIGURE 5

SHARE OF VEGETABLE OIL SUPPLY

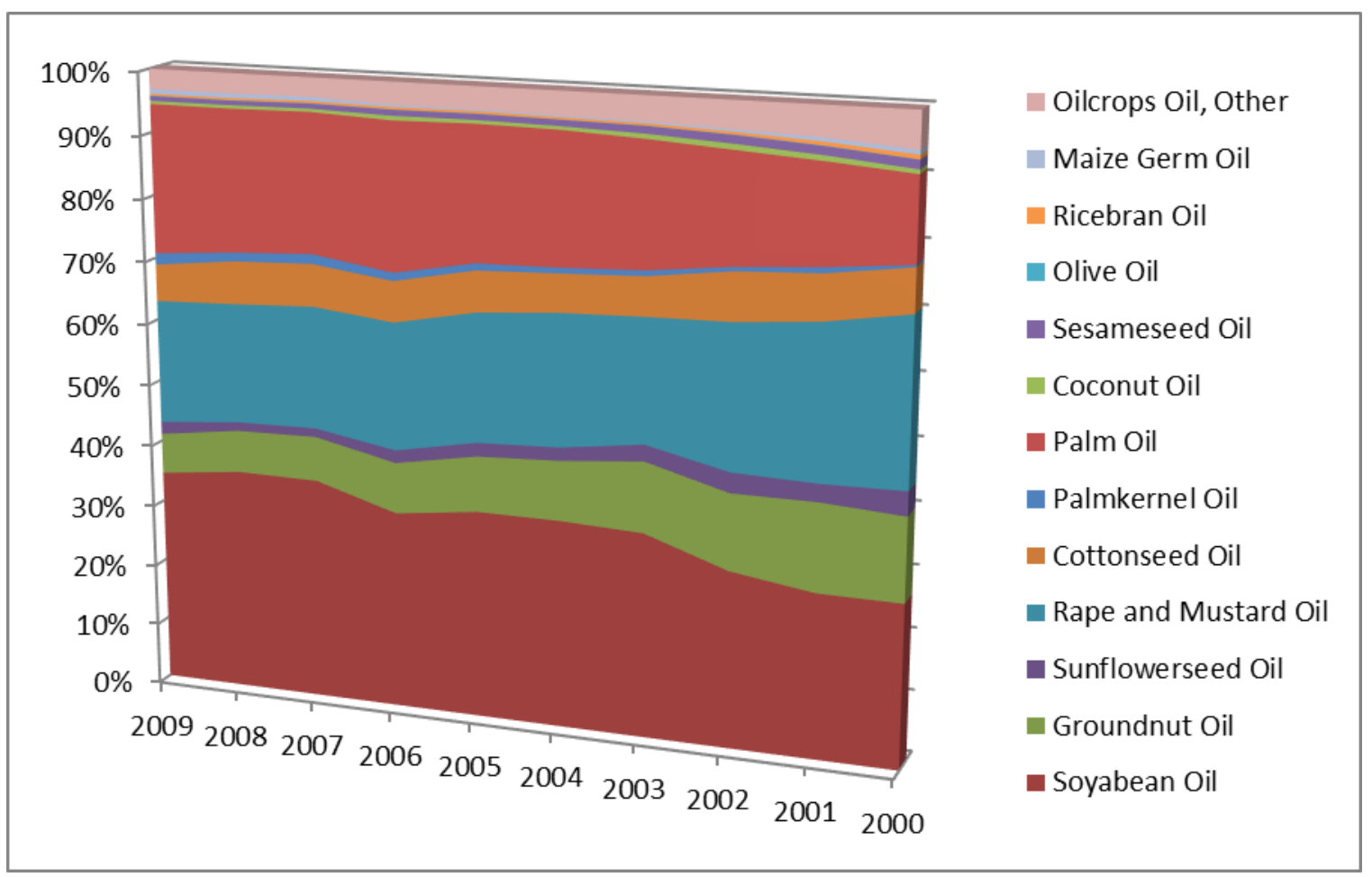

\section{FORECAST FOR VEGETABLE OIL DEMAND AND SOYBEAN IMPORTS}

Increases in income and the shift of the nation's population from the countryside to cities have resulted in significant changes in China's consumption patterns. These changes will continue as income growth and urbanization continue. According to a forecast in "Investment Blue Book: China Investment and Development Report (2003)" by the Institute of Developing Investment of China and Social Science Press, the urbanization rate will reach $70 \%$ in 2030 and $80 \%$ in 2050 , which will be the upper limit of urbanization in China. The demand for vegetable oil, therefore, will continue to increase in coming decades. However, China's consumption statistics are becoming less useful because they were designed to measure at-home consumption of basic commodities. Chinese consumers are eating more meals in restaurants, cafeterias, and dining halls, and these meals are not captured in consumption surveys. Statistics probably understate 
urban consumption of foods that are consumed outside the home (Gale, et al., 2002). That is the reason that the per capita consumption of vegetable oil in urban areas stopped increasing beginning in 2004 in table 3, and the other uses of soybean oil increased significantly each year beginning in 2002 in table 4 . To estimate the future increase of vegetable oil demand, we compare China with two East Asia countries - Japan and South Korea, which have similar food consumption patterns and higher per capita income than China. Table 5 shows the comparison. We use the per capita total vegetable oil supply to include the oil consumption outside the home. For Japan, per capita vegetable oil consumption has remained relatively unchanged for over ten years, no matter the per capita food supply or per capita total supply of vegetable oil. For South Korea, per capita total vegetable oil supply increased about $26 \%$, from $19.6 \mathrm{~kg} / \mathrm{yr}$. in 2000 to $24.8 \mathrm{~kg} / \mathrm{yr}$. in 2009. Over that same period, per capita total vegetable oil supply in China increased about $90 \%$, from 11.4 $\mathrm{kg} / \mathrm{yr}$. in 2000 to $21.7 \mathrm{~kg} / \mathrm{yr}$. in 2009. Considering China's food pattern is more like South Korea's than Japan's, we conclude that per capita total vegetable oil supply in China will increase to between $28 \mathrm{~kg} / \mathrm{yr}$. and $30 \mathrm{~kg} / \mathrm{yr}$. in the future two decades.

TABLE 4

VEGETABLE OIL SUPPLY

\begin{tabular}{|l|l|l|l|l|l|l|l|l|l|l|}
\hline Items & 2009 & 2008 & 2007 & 2006 & 2005 & 2004 & 2003 & 2002 & 2001 & 2000 \\
\hline $\begin{array}{l}\text { Vegetable Oils } \\
\text { Total }\end{array}$ & 29613 & 26617 & 26145 & 24454 & 23610 & 22151 & 20841 & 18173 & 15579 & 14803 \\
\hline Soyabean Oil & 10248 & 9605 & 9397 & 7820 & 7939 & 7439 & 6886 & 5180 & 4134 & 3912 \\
\hline Groundnut Oil & 1932 & 1810 & 1883 & 2008 & 2112 & 2126 & 2367 & 2227 & 2215 & 1996 \\
\hline $\begin{array}{l}\text { Sunflowerseed } \\
\text { Oil }\end{array}$ & 598 & 375 & 365 & 502 & 515 & 466 & 550 & 591 & 443 & 574 \\
\hline $\begin{array}{l}\text { Rape and } \\
\text { Mustard Oil }\end{array}$ & 5887 & 5119 & 5132 & 5001 & 4860 & 4666 & 4117 & 4192 & 3835 & 3937 \\
\hline Cottonseed Oil & 1743 & 1832 & 1773 & 1602 & 1547 & 1345 & 1293 & 1391 & 1120 & 1022 \\
\hline Palmkernel Oil & 540 & 370 & 407 & 319 & 262 & 196 & 183 & 121 & 143 & 48 \\
\hline Palm Oil & 7033 & 6032 & 5797 & 5757 & 5036 & 4617 & 4096 & 3141 & 2415 & 1948 \\
\hline Coconut Oil & 150 & 147 & 131 & 174 & 134 & 123 & 160 & 162 & 131 & 103 \\
\hline Sesameseed Oil & 216 & 185 & 203 & 222 & 215 & 209 & 240 & 234 & 205 & 203 \\
\hline Olive Oil & 20 & 18 & 14 & 14 & 13 & 11 & 9 & 10 & 10 & 8 \\
\hline Ricebran Oil & 90 & 90 & 90 & 90 & 90 & 75 & 75 & 75 & 90 & 98 \\
\hline $\begin{array}{l}\text { Maize Germ } \\
\text { Oil }\end{array}$ & 227 & 184 & 167 & 83 & 55 & 52 & 56 & 67 & 94 & 100 \\
\hline $\begin{array}{l}\text { Oilcrops Oil, } \\
\text { Other }\end{array}$ & 931 & 851 & 787 & 862 & 832 & 827 & 808 & 784 & 745 & 855 \\
\hline
\end{tabular}

Data Source: FAO 
TABLE 5

COMPARISON OF VEGETABLE OIL SUPPLY

\begin{tabular}{|c|c|c|c|c|c|c|c|}
\hline Country & Year & $\begin{array}{l}\text { Population } \\
\text { (Thousand) }\end{array}$ & $\begin{array}{l}\text { Supply } \\
\text { (1000 } \\
\text { tons) }\end{array}$ & $\begin{array}{l}\text { Per Capita } \\
\text { total Supply } \\
(\mathrm{Kg} / \mathrm{Yr} .)\end{array}$ & $\begin{array}{l}\text { Other } \\
\text { Uses } \\
(1000 \\
\text { tons })\end{array}$ & $\begin{array}{l}\text { Food } \\
(1000 \\
\text { tons })\end{array}$ & $\begin{array}{l}\text { Per Capita } \\
\text { food Supply } \\
(\mathrm{Kg} / \mathrm{Yr} .)\end{array}$ \\
\hline \multirow{10}{*}{ China } & 2009 & 1365580 & 29613 & 21.69 & 17332 & 12156 & 8.9 \\
\hline & 2008 & 1358790 & 26617 & 19.59 & 15735 & 10776 & 7.9 \\
\hline & 2007 & 1351832 & 26145 & 19.34 & 14846 & 11197 & 8.3 \\
\hline & 2006 & 1344764 & 24454 & 18.18 & 13408 & 10939 & 8.1 \\
\hline & 2005 & 1337612 & 23610 & 17.65 & 13544 & 9975 & 7.5 \\
\hline & 2004 & 1330416 & 22151 & 16.65 & 12452 & 9620 & 7.2 \\
\hline & 2003 & 1323107 & 20841 & 15.75 & 11182 & 9593 & 7.3 \\
\hline & 2002 & 1315485 & 18173 & 13.81 & 8860 & 9269 & 7 \\
\hline & 2001 & 1307272 & 15579 & 11.92 & 6846 & 8692 & 6.6 \\
\hline & 2000 & 1298268 & 14803 & 11.40 & 6285 & 8492 & 6.5 \\
\hline \multirow{10}{*}{ Japan } & 2009 & 126552 & 2616 & 20.67 & 680 & 1923 & 15.2 \\
\hline & 2008 & 126545 & 2737 & 21.63 & 735 & 1988 & 15.7 \\
\hline & 2007 & 126515 & 2665 & 21.06 & 662 & 1988 & 15.7 \\
\hline & 2006 & 126465 & 2733 & 21.61 & 706 & 2014 & 15.9 \\
\hline & 2005 & 126393 & 2653 & 20.99 & 632 & 2008 & 15.9 \\
\hline & 2004 & 126299 & 2647 & 20.96 & 629 & 2010 & 15.9 \\
\hline & 2003 & 126184 & 2582 & 20.46 & 671 & 1902 & 15.1 \\
\hline & 2002 & 126048 & 2553 & 20.25 & 626 & 1919 & 15.2 \\
\hline & 2001 & 125894 & 2536 & 20.14 & 550 & 1978 & 15.7 \\
\hline & 2000 & 125720 & 2538 & 20.19 & 556 & 1974 & 15.7 \\
\hline \multirow{10}{*}{ South Korea } & 2009 & 47964 & 1191 & 24.83 & 342 & 849 & 17.7 \\
\hline & 2008 & 47734 & 1000 & 20.95 & 232 & 768 & 16.1 \\
\hline & 2007 & 47499 & 964 & 20.30 & 206 & 758 & 16 \\
\hline & 2006 & 47268 & 935 & 19.78 & 218 & 717 & 15.2 \\
\hline & 2005 & 47044 & 942 & 20.02 & 232 & 711 & 15.1 \\
\hline & 2004 & 46831 & 919 & 19.62 & 205 & 714 & 15.3 \\
\hline & 2003 & 46625 & 838 & 17.97 & 194 & 644 & 13.8 \\
\hline & 2002 & 46421 & 846 & 18.22 & 269 & 577 & 12.4 \\
\hline & 2001 & 46211 & 843 & 18.24 & 269 & 573 & 12.4 \\
\hline & 2000 & 45988 & 806 & 19.62 & 211 & 595 & 12.9 \\
\hline
\end{tabular}

Data Source: FAO

The level of China's soybean imports depends on the demand for vegetable oil and the domestic production of oil crops as well as imports of other oil crops and crop oil. On the demand side, based on world population prospects by the United Nation, China's population will achieve 1.396 billion in 2026 and 
then drop quickly (Nations, 2010). If per capita total vegetable oil supply in China remains stable at 28 $\mathrm{kg} / \mathrm{yr}$. to $30 \mathrm{~kg} / \mathrm{yr}$., the highest demand for vegetable oil would be 39 million tons to 42 million tons. If soybean oil retains one-third of the share of total vegetable oil consumption, the supply of soybean oil would be between 13 million tons to 14 million tons. Considering massive soybean oil crushing capacity in China, imports of soybean oil will be less than 2 million tons. Therefore, the total production of soybean oil will be between 11 million tons and 12 million tons, which means the demand for soybeans used to crush oil will be 60 million tons to 65 million tons.

On the supply side, soybean production in China is concentrated in the Northeast (Heilongjiang and Jilin) and the North China Plain (Shandong, Henan, and Hebei). These two regions together produce about $60 \%$ of China's soybeans. The North China Plain is largely a double-crop region, and its summer soybean output is crippled by low yields due to a short growing season. It would be neither agronomically feasible nor economically practical to substitute two crops - mainly winter wheat and summer corn, or cotton - for a single crop of soybeans sown in the spring. Soybean output therefore can only be significantly expanded if China shifts large areas of corn or spring wheat in the Northeast region into soybean production (Tuan, et al., 2004). Policy makers in China were concerned primarily with supplying enough grain to meet basic nutritional needs of China's vast population (Gale, et al., 2002). Limited to arable land and slow growth of soybean yields, the production is not expected to change considerably in the future two decades.

Based on the trends discussed above and taking into account soybeans used for food, feed, export, seed, and waste, the shortage of soybeans should be 60 million tons to 65 million tons by 2026, which will be the future demand for soybean imports in China. Several factors might affect the vegetable oil demand and the soybean oil demand. First, fat consumption may be governed, not by physiological mechanisms, but by the amount of fat available in the food supply (Drewnowski and Popkin, 1997). China's consumers are sensitive to food prices, suggesting that realignments of prices could have serious effects on oil demand. If vegetable oil prices increase significantly, the demand would be curbed. Second, little is known about how China's consumers will respond to genetically modified organisms (GMOs), which could play a crucial role in China's future consumption and trade. Although the Chinese government continues to be active in setting policies - it issued import certificates for three GMO soybeans in June 2013 - the opponents of GMOs have increased markedly in recent years. Consumer's opposition will lead to a decrease in consumption of GMO soybean oils, which account for half of the total supply. Third, vegetable oil is a strong substitute for soybean oil. If consumers do not have access to enough soybean oil, they would turn to ground nuts oil or palm oil. Continually increasing demand has led to significant soybean oil price increases in recent years, which in turn has propeled Chinese importers to look for substitutes. Palm oil imports have therefore increased continually in the decade of the 2000 's. In 2009 , palm oil accounted for $24 \%$ of total vegetable oil supply. Palm oil plays a leading role in the global vegetable oil market. So it will impact the leading role of soybean oil in China. However, one limitation is that importing palm oil cannot offer feed for the livestock industry like crushing soybeans.

\section{CONCLUSION}

Increasing income and urbanization led to increasing edible oil consumption. With the rapidly-changing patterns of oil consumption in China over the decades of the 1990's and 2000's, consumption of soybean oils has been experiencing faster growth than consumption of rapeseed and peanut oils has, inducing massive soybean demand, particularly for crushed soybean oil and meal. China's strained natural resources and high levels of fertilizer and pesticide use mean that further expansion of agricultural output through greater input may not be sustainable. To accommodate growing consumer demand for food, the agricultural sector will probably need to make more efficient use of its limited land. Therefore, with increasing integration with the global economy, China's trade pattern in agricultural commodities follows its

comparative advantage: it imports land-intensive commodities (soybeans, cotton, barley, rubber, and oils made from soybeans and palm kernels), and exports labor-intensive commodities (fish, fruits, vegetables, and processed agricultural goods). Importing soybeans, which have low yields per hectare, allows China to free up land for higher yielding crops. This shift of arable land to higher yielding crops, which has been 
adopted as agricultural policy by the Chinese government, will cause the shortage of soybean supply to persist for the long term.

Comparing vegetable oil consumption in China with consumption in Japan and South Korea, two neighboring countries with similar food consumption patterns, we estimate that the per capita vegetable oil supply will achieve 28-30 kg/yr in the decade of 2024's, and the shortage of soybean supply will be about 60-65 million tons. Prices of other edible oils, panic among consumers over potential risks of GMOs, and competition from other substitutes will also affect the demand for soybean imports.

\section{ACKNOWLEDGEMENTS}

The authors would like to thank Kenn Webb, Shareholder in the law firm Ferguson Braswell Fraser Kubasta PC of Plano, Texas, for his valuable insights and editorial contributions.

\section{REFERENCES}

Drewnowski, A., \& Popkin, B.M. (1997). The nutrition transition: New trends in the global diet. Nutrition Reviews, 55(2), 31-43.

Gale, F., Tuan, F., Lohmar, B., Hsu, H.H., \& Gilmour, B. (2002). China's Food and Agriculture: Issues for the 21st Century. Agriculture Information Bulletin No. (AIB-775) 68.

Huang, J., Rozelle, S., \& Rosegrant, M.W. (1999). China's Food Economy to the Twenty-first Century: Supply, Demand, and Trade. Economic Development and Cultural Change, 47, 737-766.

Nations, U. (2011). World Population Prospects: The 2010 Revision (Volume I). Comprehensive Tables, New York.

Tuan, F.C., Fang, C., \& Cao, A.Z. (2004). China's Soybean Imports Expected to Grow Despite ShortTerm Disruptions. Electronic Outlook Report from the Economic Research Service.

USDA. (2010, February 10). Oilseeds: World Markets and Trade. Foreign Agricultural Service Circular Series FOP 2. 